\title{
Merjenje kakovosti, usmerjenost $k$ uporabniku in davčna administracija
}

UDK: $331.108 .5: 336.27$

\author{
Maja Klun \\ Univerza v Ljubljani, Fakulteta za upravo \\ maja.klun@fu.uni-lj.si
}

\begin{abstract}
IZVLEČEK
Merjenje kakovosti in usmerjenost $k$ uporabniku je sestavni del reform javnega sektorja in zato tudi sestavni del sprememb dela davčnih administracij povsod po svetu. $V$ članku je na začetku predstavljen odziv davčnih administracij v svetu na te spremembe, v drugem delu pa so prikazani rezultati raziskav o mnenju uporabnikov slovenske davčne uprave (davčnih zavezancev) o njenem delu, torej kakovosti izvajanja storitev in njeni usmerjenosti $k$ uporabniku. Ker gre za raziskave, ki so bile izvedene $v$ različnih časovnih obdobjih, je podana tudi primerjalna analiza rezultatov, predvsem glede tega, ali so zavezanci bolj zadovoljni $z$ delom davčne uprave ali ne.
\end{abstract}

Ključne besede: davčna uprava, kakovost, usmerjenost k uporabniku, mnenje zavezancev.

\section{Uvod}

Usmerjenost $\mathrm{k}$ uporabniku in merjenje kakovosti $v$ javnem sektorju in $\mathrm{s}$ tem $\mathrm{v}$ javni upravi postaja pomemben element reforme javnega sektorja tudi $\vee$ Sloveniji. Sistematično se je to področje začelo urejati leta 1999, ko je bil pri ministrstvu za notranje zadeve ustanovljen odbor za kakovost. Leta 2001 so bile številne dobre prakse uveljavljene kot obvezni standard v poslovanju s strankami, z letom 2002 pa je bil vpeljan $v$ javno upravo tudi evropski model ocenjevanja kakovosti (C. A. F.). To so le osnovne podlage za uvajanje kakovosti in večje usmerjenosti k uporabniku javnih storitev. Kot del javne uprave se s temi ukrepi srečuje tudi davčna uprava.

Namen tega članka je predstaviti ukrepe za večjo usmerjenost $k$ uporabniku in merjenje kakovosti $v$ razvitih davčnih upravah ter stanje $v$ Sloveniji. Prvi dve poglavji tako vsebujeta ukrepe in prikaz nekaterih dobrih praks tujih davčnih uprav na področju usmerjenosti k uporabniku in merjenja kakovosti dela davčnih uprav. Tretje poglavje prinaša ugotovitve merjenja kakovosti in mnenja strank o delu davčne uprave $\vee$ Sloveniji. Gre za prikaz rezultatov štirih raziskav, v katerih so davčni zavezanci podali svoje mnenje o delovanju davčne uprave. 
Maja Klun

Merjenje kakovosti, usmerjenost $k$ uporabniku in davčna administracija

\section{Usmerjenost $k$ uporabniku in davčna administracija}

Usmerjenost k uporabniku je vključena v večino reform javnega sektorja. Gre sicer za načelo, ki je relativno novo, pa kljub temu $\vee$ razvitih državah že precej uveljavljeno (civil initiatives, civil charters ipd.). V okviru javne uprave so za zadovoljstvo uporabnika potrebne predvsem naslednje storitve: enostavnost, informiranje, dostopnost, kakovost in strokovnost. Usmerjenost $k$ uporabniku naj bi bila prisotna na vseh ravneh delovanja javne uprave, torej tudi pri delu davčnih administracij. $\vee$ večini držav želijo izboljšati storitve, namenjene davkoplačevalcem, saj je to sestavni del sodobnega davčnega sistema, če želi biti uspešen, po drugi strani pa gre za novo oblikovanje odnosov med davčno administracijo in zavezanci.

$\checkmark$ zasebnem sektorju je idealna storitev za stranko opredeljena kot zadovoljstvo ali s krilatico 'stranka ima vedno prav'. Tega odnosa ne moremo preprosto prevesti $\vee$ javni sektor, saj stranka ni samo posameznik kot tak, ampak jo javni sektor uvršča v neko kategorijo. Doseganje odnosa, ki velja med stranko in ponudnikom, je kljub temu možno s prilagoditvijo uvajati v javni sektor. Davčne administracije tak odnos lahko dosežejo z zniževanjem posrednih stroškov obdavčenja, zmanjševanjem števila stresnih situacij za zavezanca, z izboljšanjem komunikacije in lažjim dostopom do informacij.

Davčna administracija se mora zavedati, da ni represivni organ države, ampak je njena naloga poleg pobiranja davkov še svetovanje in obveščanje javnosti o svojem delu. Če je svetovanje dobro razvito, če je delovanje davčne uprave dovolj javno, je tudi uspešnost davčne administracije večja, predvsem zaradi večjega prostovoljnega prijavljanja davkov. S svetovanjem ni mišljen le neposreden odnos med zavezancem in upravo ob nastalih nejasnostih in problemih, ampak tudi oblikovanje jasnih navodil zavezancem za izpolnjevanje obveznosti, obveščanje o predvidenih spremembah in organiziranje delavnic za izobraževanje zavezancev. Čim preprostejša so navodila, tem večja je verjetnost, da bo večina zavezancev pravilno izpolnila svoje davčne obveznosti.

Obveščanje javnosti ne pomeni samo predstavljanja obveznosti davkoplačevalcev, pomembno je tudi obveščanje o delovanju davčne uprave in njeni uspešnosti. Davkoplačevalci so namreč dovzetnejši za informacije o tem, kaj je davčna uprava storila $\vee$ preteklosti, kot pa o tem, kaj bo storila $\vee$ prihodnosti. Posebej to velja za informacije o odkrivanju utaj in uspešnem reševanju pritožb.

Storitve davčnih administracij lahko združimo v tri osnovne skupine (Lebaube in Vehorn, 1992, str. 310): svetovanje zavezancem ter njihovo informiranje in izobraževanje. Glavni namen svetovanja je razlaganje kompleksnih, včasih celo nasprotujočih si zakonskih predpisov, povezanih z davčno obveznostjo posameznika. Po nekaterih podatkih je bila stopnja prostovoljnega izpolnjevanja obveznosti v 


\section{Merjenje kakovosti, usmerjenost $k$ uporabniku in davčna administracija}

ZDA najvišja ravno v času, ko je bil delež zaposlenih, ki so se ukvarjali s svetovanjem zavezancem, v davčni administraciji najvišji (5,8 \%).

Informiranje zavezancev lahko poteka z različnimi načini obveščanja. Lebaube in Vehorn (1992, str. 318) sta jih združila v šest skupin: publikacije, mediji, telefonski kontakti, osebni obiski, pisna navodila in drugi programi informiranja, ki so se razvili v nekaterih državah (prostovoljci, izobraževanje dijakov ...).

Tehnični komite pri OECD je konec osemdesetih let svojo posebno dejavnost ${ }^{\mathbf{1}}$ na področju odnosov med prebivalci in državno upravo začel s projektom proučevanja odnosov med zavezanci in davčno administracijo. Odzivnost davčne administracije je opredeljena kot (Administrative Responsiveness and the Taxpayer, 1988, str. 1) zmožnost davčne administracije, da služi potrebam svojih strank. Odzivnost davčne administracije se kaže $v$ vljudnem in pravočasnem odnosu do zavezancev ter $v$ izboljševanju komunikacije med obema. Pomembna je sprememba 'kulture' organizacije. V priporočilih OECD (1988) je izboljšanje storitev opredeljeno kot:

- jasna predstavitev (s postopki, obrazci in jezikom) pravic in obveznosti davkoplačevalcem,

- uporaba prednosti informacijske tehnologije za hitro, preprosto in točno obdelavo podatkov in obveznosti ob hkratnem upoštevanju zaupnosti podatkov,

- vpliv na pravičnost sistema.

Pri zagotavljanju boljših storitev naj bi davčna administracija spodbujala zavezance, ki prostovoljno izpolnjujejo svoje obveznosti, zmanjšala število prenizkih plačil, ki izhajajo iz napak in nerazumevanja davčnih obveznosti, ter preprečevala delovanje tistih, ki prikrivajo svoje davčne obveznosti. Odzivnost davčne administracije je močno odvisna (Administrative Responsiveness and the Taxpayer, 1988, str. 2) od zaposlenih, njihove motiviranosti, morale, internega komuniciranja in pravilnega vodenja. Zaradi različnih političnih teženj in vplivov je ravno zadnji dejavnik velikokrat vprašljiv.

Davčna administracija s svojo specifično vlogo $v$ javnem sektorju lahko $z$ napačno politiko postane represiven organ, katerega glavni namen je samo pobiranje davčnih prihodkov. Pri tem se velikokrat pojavi vprašanje, ali ni dolžnost davčne administracije, da opozori zavezanca, da je plačal previsok znesek davka zaradi nepoznavanja olajšav. Empirično je (Hasseldine, 1998, str. 11) dokazano, da dobra komunikacija med zavezanci in davčno administracijo povečuje davčne prihodke, manj empiričnih dokazov je, da storitveno usmerjena davčna administracija zmanjšuje stopnje davčnih utaj in izogibanj, čeprav bi lahko sklepali, da ta vpliv obstaja.

1 Označil jo je s kratico CITAD (odnos med prebivalci in javno upravo) ter CITAX (odnos med zavezanci in davčno administracijo). 
Maja Klun

Merjenje kakovosti, usmerjenost k uporabniku in davčna administracija

Graditev pozitivne podobe davčne administracije je ravno tako pomemben dejavnik storitveno usmerjene uprave.

Večina držav članic OECD se je odzvala na omenjeni projekt in navedla poglavitne ukrepe za izboljšanje odzivnosti davčne administracije $v$ svojih državah (Administrative Responsiveness and the Taxpayer, 1988):

- poglavitni cilj večine davčnih reform je bila poenostavitev sistema;

- izvedeni so bili številni ukrepi za izboljšanje razumljivosti obrazcev in njihovo poenostavitev; ${ }^{2}$

- vrsta ukrepov za izboljšanje informiranosti zavezancev: brezplačne telefonske linije, potujoče svetovalnice, dnevi odprtih vrat, forumi za izmenjavo informacij med zavezanci in administracijo, svetovalnice 'vse na enem mestu', posebno izobraževanje za predstavnike medijev, videokasete o tem, kako pravilno izpolniti davčno napoved;

- oblikovanje načinov informiranja za različne ciljne skupine;

- oblikovanje kodeksa etike in pravic zavezancev;

- promocija interne komunikacije (interni časopisi, forumi ipd.);

- izobraževanje zaposlenih za izboljšanje komunikativnih sposobnosti in spoznavanje celotnega davčnega sistema, oblikovanje posebnih oddelkov, ki skrbijo za stike z zavezanci;

- izvajanje letnih anket med zavezanci, s katerimi davčne administracije ocenjujejo uspešnost svojega delovanja ter na podlagi katerih oblikujejo nadaljnjo politiko razvoja odnosa z zavezanci;

- oblikovanje in programi razvoja kariere zaposlenih $v$ davčnih administracijah;

- decentralizacija delovanja, povečevanje števila manjših uradov.

Kljub različnim pozitivnim ukrepom $v$ državah OECD za graditev dobrega odnosa med zavezanci in administracijo $\vee$ praksi nekateri ukrepi pomenijo zgolj popravke, ki so sicer pisno opredeljeni, vendar se ne izvajajo $v$ celoti.

\section{Merjenja kakovosti in odnosa zavezancev}

Naj opozorimo na enega od zgoraj navedenih ukrepov, in sicer izvajanje letnih anket med zavezanci. Merjenje uspešnosti in učinkovitosti delovanja davčne administracije naj bi vključevalo tudi ocenjevanje kakovosti dela. Kot stranke davčne uprave lahko opredelimo dva subjekta. Prvi subjekt, ki ocenjuje delo davčne uprave, je država, drugi pa so zavezanci. Interes države je usmerjen predvsem $v$ učinkovitost pobiranja davčnih prihodkov, interes zavezancev pa je drugačen. Večina se zaveda, da je plačevanje davkov nujno in zato to želi opraviti čim manj stresno. To pomeni, da ocenjuje delo davčne uprave predvsem v smislu,

2 Tak ukrep je, da večina dohodninskih zavezancev prejme že izpolnjeno napoved in jo samo podpiše (npr. Švedska, Danska). 


\section{Merjenje kakovosti, usmerjenost $k$ uporabniku in davčna administracija}

ali ji ta daje dovolj informacij, ali je pri pobiranju davkov korektna, ali so zaposleni dovolj prijazni ipd.

$\checkmark$ nadaljevanju bomo obravnavali, kako zavezanci ocenjujejo kakovost dela davčne uprave. Kakovost dela lahko ocenjujejo interni nadzorni organi ali zunanji strokovnjaki, vendar je njihova vloga pomembna predvsem pri ocenjevanju zakonitosti postopkov, profesionalnosti, izpolnjevanja standardov ipd. Deloma bi kakovost dela lahko ocenjevali s pomočjo analiziranja pritožb (koliko pritožb je upravičenih, koliko jih izhaja iz napak dela davčne uprave, hitrost reševanja pritožb in drugih zahtevkov ipd.). V Veliki Britaniji kakovost dela davčne uprave ocenjujejo s standardi, ki jih pomaga določiti civilno združenje zavezancev (npr. zabeležiti 99 \% plačil zavezancev pravilno, 82 \% pisnih zahtevkov zavezancev rešiti v 14 dneh, na $95 \%$ klicev odgovoriti z zadovoljivim odgovorom za zavezance ipd.), vendar pa v večini držav članic OECD merjenje kakovosti dela opravljajo z anketami med zavezanci.

OECD (2001a) v svojem poročilu navaja, da večina držav OECD z anketami preverja mnenje zavezancev o delu davčne uprave. Norveška davčna uprava redno izvaja ankete med zavezanci za ocenjevanje svojega dela, medtem ko nizozemska davčna uprava ankete vedno izvaja ob spremembah $v$ davčni zakonodaji. $\checkmark$ Danski in Nemčiji ankete niso redne, se pa izvajajo $v$ določenih intervalih. Po drugi strani $v$ nekaterih državah ankete med zavezanci opravljajo različne javne in zasebne institucije. Tako so ankete pogoste v Švedski, Finski, ZDA, Španiji, Novi Zelandiji, Švedski in Franciji. V Mehiki, Kanadi in Veliki Britaniji davčna uprava redno organizira srečanja s posameznimi skupinami zavezancev ali njihovimi predstavniki in na podlagi teh razgovorov dobi povratno informacijo o svojem delu. $V$ drugih državah so ankete občasne. Ne glede na pogostost izvajanja anket pa rezultati ankete vplivajo na samo delo davčne administracije.

Naj omenimo nekaj zanimivih ukrepov nekaterih davčnih uprav, ki so bili posledica analize anket med zavezanci (Rains, Febres in Bes, 1997, str. 209):

- Davčna administracija $\vee$ Čilu je sprejela maksimalni čas čakanja za reševanje problemov davkoplačevalcev, ko se ti oglasijo na davčnem uradu. Poleg tega mora biti problem rešen ob enem obisku, kar pomeni, da morajo imeti uradniki na razpolago določene obrazce za dopolnitev davčne prijave ipd.

- Mehiška davčna administracija ima 8 mobilnih enot, ki svetujejo na terenu. Te enote so namenjene predvsem obiskovanju manjših krajev, kjer ni davčne izpostave. Uvedli so tudi avtomatski telefonski odzivnik, ki ponavlja odgovore na najpogostejša vprašanja zavezancev, ki so razvrščena $v$ pet skupin (poslovanje s tujino, fizične osebe, pritožbe, splošne informacije, fiskalni kazalci).

- Ameriška IRS je oblikovala posebno skupino svetovalcev, ki pomagajo starejšim zavezancem. 
Maja Klun

Merjenje kakovosti, usmerjenost k uporabniku in davčna administracija

- Kanadska davčna uprava vsako leto izvede program 'Učimo se o davkih', $\checkmark$ okviru katerega davčni uslužbenci organizirajo tečaj na različnih srednjih šolah, kjer predstavijo osnovne davčne pojme in delovanje davčnega sistema. Vsako leto organizirajo s pomočjo prostovoljcev $v$ lokalnih skupnostih tečaj izpolnjevanja dohodninske napovedi za zavezance (Baker, 1997, str. 194).

- V odnosu do zavezancev je postalo poglavitno vodilo singapurske davčne uprave, da večina davkoplačevalcev želi izpolniti svoje davčne obveznosti, zato je bil ustanovljen svetovalni servis 'vse na enem mestu' za zavezan$c e, k i$ je razdeljen $v$ tri sekcije. Preproste primere rešuje prva sekcija, če pa je problem kompleksnejši, zavezanca pošljejo $v$ drugo ali tretjo sekcijo. Po nekaterih ocenah je večina preprostih problemov rešena prej kot $v 10$ minutah, če pa so potrebne dopolnitve vlog ali druga korespondenca, pa prej kot $v$ enem mesecu (Kien in Siong, 1998, str. 506). Spodbujanje prostovoljnega izpolnjevanja davčnih obveznosti je potekalo še na druge načine: poenostavljajo obrazce za napovedovanje davčne obveznosti; vsakega pol leta se srečujejo s predstavniki podjetij, s katerimi razpravljajo o problemih, povezanih z jasnostjo posameznih davkov, olajšav ipd. Davčna uprava izdaja mesečni časopis, $v$ katerem obvešča zavezance (predvsem podjetja) o tekoči problematiki drugih podjetij in njihovem reševanju konkretnih primerov. Zavezancem je omogočen dostop do davčne računalniške baze, kadar želijo spremeniti podatke o naslovu oz. ko po internetu oddajajo napovedi.

\section{Slovenska davčna uprava in zavezanci}

Slovenska davčna uprava je že $v$ svojem strateškem načrtu za obdobje 1998-2000 določila, da je treba izvesti več ukrepov, ki bodo zavezance spodbudili k prostovoljnemu izpolnjevanju davčnih obveznosti, s tem pa k večji usmerjenosti k uporabniku in kakovosti storitev. Naj med pomembnejšimi omenimo le nekatere:

- izdajanje revije Davčni bilten, ki zavezance seznanja s posameznimi odločitvami davčne uprave $v$ posameznih postopkih in najpogostejših napakah zavezancev,

- spletna stran DURS, ki daje zavezancem vrsto osnovnih informacij o obveznostih, povezanih z davki, in

- portal E-davki, ki od letošnjega leta ponuja tudi elektronsko prijavljanje nekaterih davčnih obveznosti.

Poleg zgoraj omenjenih ukrepov za zavezance je svojim zaposlenim DURS pripravila Napotke za ravnanje s strankami (2000), sprejet pa je bil tudi Kodeks etike obnašanja davčnih uslužbencev. 


\section{Merjenje kakovosti, usmerjenost $k$ uporabniku in davčna administracija}

Anketiranje zavezancev $\vee$ Sloveniji ni stalna praksa DURS pri preverjanju njene kakovosti. $V$ javnosti sta znani dve raziskavi med zavezanci, ki ju je naročila davčna uprava, in sicer anketiranje zavezancev novembra 1996 (raziskavo je opravilo podjetje Varianta, d.o.o) in junija 2003 (Gral-Iteo). Na Fakulteti za upravo smo raziskavo izvedli za leto 2000 in 2002 . To niso edine izvedene ankete med zavezanci, saj strokovne revije občasno opravljajo manjše raziskave med zavezanci, povezane predvsem s posamezno aktualno problematiko. $V$ naši analizi bomo te manjše raziskave zanemarili in skušali primerjati rezultate raziskav, ki jih je objavila DURS, in rezultate, ki smo jih opravili na Fakulteti za upravo. Neposredna primerjava je nemogoča zaradi različnih metodologij, različne strukture vprašanj in vzorcev. Kljub temu bomo skušali primerjati skupne ugotovitve in oceniti, ali se je mnenje zavezancev izboljšalo med različnimi obdobji, $\vee$ katerih so bile ankete izvedene.

Ugotovitve po posameznih raziskavah:

$\checkmark$ raziskavo leta 1996 (Derganc, 2000) so bile vključene pravne osebe in samostojni podjetniki posamezniki (s. p. p.), skupaj 156 zavezancev iz vseh panog (57,2 \% majhnih podjetij in s. p. p., 28,3 \% srednjih podjetij in 6,6 \% velikih podjetij). Večinoma so na vprašanja odgovarjali zaposleni v finančno-računovodski službi oz. samostojni podjetniki posamezniki. Zavezanci so s pomočjo vprašanj ocenjevali predvsem:

- $\quad$ kakovost informacij, ki jih nudi davčna uprava,

- poglavitne vire informacij za izpolnjevanje davčnih obveznosti,

- zahtevnost izpolnjevanja posameznih davčnih obveznosti,

- $\quad$ korektnost dela zaposlenih $\vee$ davčni kontroli in davčni inšpekciji.

Rezultati ankete so pokazali, da zavezanci največ informacij pridobijo s pomočjo strokovnih publikacij, sledijo znanci v drugih podjetjih, na tretjem mestu pa so seminarji in strokovna predavanja. Čeprav so bili davčni svetovalci šele na zadnjem mestu, pa je kakovost njihovih informacij ocenjena najvišje, sledijo seminarji in strokovna predavanja. Tretjo najboljšo povprečno oceno so zavezanci glede kakovosti namenili davčnim uslužbencem. Na vprašanje o tem, kakšen bi bil najprimernejši način informiranja davčnih zavezancev, so ti na prva tri mesta postavili publikacije, medije in izobraževalne programe.

Pri vprašanju o tem, kako bi ocenili zadovoljivost informacij davčne uprave, so zavezanci, ki so poiskali pomoč na davčni upravi, to ocenili srednje, tretjina pa je bila nezadovoljna. Najbolj so bili nezadovoljni tisti zavezanci, ki so pomoč na davčni upravi iskali pisno, najbolj pa so bili zadovoljni tisti, ki so davčno upravo obiskali osebno.

Glede enostavnosti so zavezanci kot najenostavnejši ocenili dve davčni obveznosti, in sicer prispevke za socialno zavarovanje in davek na izplačane plače. Kot 
Maja Klun

Merjenje kakovosti, usmerjenost k uporabniku in davčna administracija

najzahtevnejši davek je bil ocenjen davek od dobička pravnih oseb, drugi najzahtevnejši davek pa takratni prometni davek.

Pri ocenjevanju davčnega nadzora so zavezanci ocenili, da imajo davčni kontrolorji prepogosto zavezance vnaprej za utajevalce, medtem ko se davčni inšpektorji obnašajo avtoritativno in birokratsko, vendar jim po drugi strani priznavajo tudi korektnost.

Zavezanci so imeli deljeno mnenje o tem, kako je poskrbljeno za varnost njihovih podatkov, največja pomanjkljivost DURS pa je po mnenju zavezancev preveč administracije in premalo usposobljenih kadrov.

V raziskavi leta 2003 so bili temeljni cilji (Konič, Arh, 2003):

- ugotoviti, kakšen je ugled DURS,

- kaj o sodelovanju z DURS menijo zavezanci in

- kaj mora DURS storiti za izboljšanje storitev za davčne zavezance.

$\checkmark$ raziskavo je bila $\vee$ nasprotju z raziskavo $\vee$ letu 1996 poleg pravnih oseb $(23,2 \%)$ in s. p. p. $(25,6 \%)$ vključena še t. i. širša javnost $(51,2 \%)$. V vzorec je bilo vključenih skupaj 1960 zavezancev.

Največji ugled ima DURS med širšo javnostjo, medtem ko najslabše delo DURS ocenjujejo tisti zavezanci, ki imajo pogosteje stik z davčno upravo ali pa so z njo $\vee$ postopku. Zavezanci so najbolje ocenili varovanje podatkov, hitrost pri odmerjanju davkov, preglednost nad prihodki zavezancev, pravočasnost opozarjanja na napake in trditev, da zaposleni niso podkupljivi. Kritični so bili do trditev o tem, da davčna uprava $v$ okviru zakonodaje deluje $v$ korist zavezancev, da enako za vse zavezance tolmači zakonodajo $v$ vseh situacijah, da je fleksibilna in da ima pozitivno podobo $v$ medijih.

Glede informiranja o davčnih obveznostih je davčna uprava zasedla drugo mesto, medtem ko imajo zavezanci DURS za manj koristen vir informacij o novostih. Kot veliko pomanjkljivost pri dajanju informacij zavezanci navajajo preslabo strokovnost in obveščenost zaposlenih na DURS. Zavezanci si želijo večjo preglednost in jasnosti navodil ter redne publikacije, s katerimi bi jih DURS obveščala o davčnih predpisih, zakonih in drugem. Poslovna javnost sicer meni, da se je DURS-ovo informiranje $v$ zadnjih letih izboljšalo, širša javnost pa meni, da se ni spremenilo. Zavezanci so večinoma zadovoljni z obrazci in jih ne ocenjujejo kot zahtevne.

Pri ocenjevanju dela davčnih kontrolorjev so zavezanci večinoma zadovoljni, saj so ti po njihovem mnenju prijazni in natančni, vendar še vedno premalo strokovni. Večina zavezancev ocenjuje, da se je njihovo delo izboljšalo $v$ zadnjih letih. Podobno so ocenili tudi delo inšpektorjev. 


\section{Merjenje kakovosti, usmerjenost $\mathbf{k}$ uporabniku in davčna administracija}

Raziskava za leto 2000 (Klun, 2002) je ravno tako preverjala odnos zavezancev do dela DURS. Zavezanci so ocenjevali različne trditve, povezane z delom DURS, $\vee$ raziskavo pa so bile vključene tako pravne osebe, zastopane po vseh panogah, $(25,5 \%)$ kot fizične osebe $(74,5 \%)$. Analiza vsebuje odgovore 298 zavezancev. $\vee$ okviru raziskave so zavezanci ocenjevali (z ocenami od 1 - se sploh ne strinjam - do 4 - se popolnoma strinjam) različne trditve, povezane z odnosom zavezancev do dela davčne uprave.

Zavezanci so najslabše ocenili trditev, da je davčna uprava učinkovita pri odkrivanju davčnih utaj. Podatki davčne uprave kažejo, da sicer davčna uprava pri davčnem nadzoru odkrije precej nepravilnosti, saj je delež ugotovljenih nepravilnosti v vseh pregledih preko $50 \%$, prav tako se povečuje tudi vrednost odkritih utaj, zato ne bi mogli sklepati, da je delo davčne uprave na tem področju slabo. Vendar pa je uspešnost tega dela slaba, če zavezanci menijo, da delo na tem področju ni dobro. Deloma so te ocene povezane s tem, da so v medijih bolj odmevne kritike kot pa uspešno odkrivanje utaj, deloma pa k temu pripomore tudi dejstvo, da je $v$ velikih mestih pogostost pregledov precej nizka in zato zavezanci menijo, da je verjetnost odkritja davčne utaje manjša, kar so tudi potrdili $\vee$ svojih trditvah $\vee$ anketi. Mnenje o neučinkovitosti je verjetno deloma povezano tudi s podatki o velikem davčnem dolgu, ki je posledica precej velikega zabilančnega dolga (to je dolga, pri katerem so bile izkoriščene že vse možnosti za izterjavo), deloma pa tudi načina odplačevanja davčnega dolga, saj se najprej odplačujejo obresti in šele nato glavnica, kar pa skupni dolg zavezanca stalno povečuje in zmanjšuje njegovo zmožnost plačila. $V$ tujini se skušajo izogniti povečevanju davčnega dolga tudi tako, da omogočajo pogajanja o plačilu dolga in/ali omogočajo samoovadbo, ki precej zniža kazni.

Slabo so zavezanci ocenili še hitrost dela davčne uprave in obveščanje zavezancev. Po drugi strani pa so zavezanci z najvišjimi ocenami ocenili trditve o tem, da so zaposleni na davčni upravi pošteni, da ima davčna uprava dobro zabeležene vse podatke o zavezancih in da zaposleni pomagajo pri vprašanjih, povezanih z davčnimi obveznostmi.

Zanimivo je, da so zavezanci, ki imajo negativne izkušnje z davčno upravo, kot glavni vzrok navedli nestrokovnost zaposlenih na davčni upravi in kot drugo nepravočasnost pri odločanju.

Največ zavezancev, ki jih lahko uvrstimo $v$ poslovno javnost, je uporabljalo pisna navodila davčne uprave $(68,7 \%)$, dobra polovica pa jih je obiskala davčni urad ali izpostavo davčnega urada. Koristnost obiska davčnega urada oz. izpostave je kot najslabše ocenilo 17,6 \% tistih, ki so želeli pridobiti informacije na ta način. Najbolje je večina ocenila pisna navodila.

Pri ocenjevanju enostavnosti izpolnjevanja davčnih obveznosti dohodnine, davka od dobička pravnih oseb in DDV so kot najzahtevnejše zavezanci ocenili izpolnjevanje obveznosti, povezanih z DDV, sledil je davek od dobička pravnih 
Maja Klun

Merjenje kakovosti, usmerjenost $k$ uporabniku in davčna administracija

oseb, najenostavnejša pa je bila za zavezance dohodnina, saj je več kot $81 \%$ zavezancev za dohodnino menilo, da je izpolnjevanje obveznosti enostavno. Verjetno je $k$ tej razporeditvi veliko prispevalo dejstvo, da je bil DDV $\vee$ času raziskave relativno nova davčna obveznost.

$\checkmark$ raziskavi, ki je potekala konec leta 2002 in v začetku leta 2003, smo z enakimi vprašanji (z ocenami od 1 do 4) ocenjevali odnos zavezancev do DURS. V vzorec so bile zopet vključene tako pravne $(67,3 \%)$ kot fizične $(32,7 \%)$ osebe, skupaj je analiziranih 187 odgovorov.

$\checkmark$ spodnji tabeli podajamo povprečno oceno za posamezno trditev, povezano z ocenjevanjem dela DURS, skupaj s povprečjem ocen iz raziskave za leto 2000.

Tabela 1: Ocene zavezancev o delu davčne uprave

\begin{tabular}{|l|c|}
\hline trditev & $\begin{array}{c}\text { povprečna ocena 2002 } \\
\text { (povprečna ocena 2000) }\end{array}$ \\
\hline $\begin{array}{l}\text { Delavci na davčni upravi vedno pomagajo v zvezi z } \\
\text { davčnimi vprašanji. }\end{array}$ & $\begin{array}{c}2,53 \\
(2,51)\end{array}$ \\
\hline Zaposleni na davčni upravi so učinkoviti. & 2,46 \\
& $(2,14)$ \\
\hline Zaposleni na DURS so dovolj izobraženi za svoje & 2,40 \\
delo. & $(2,37)$ \\
\hline Zaposleni na davčni upravi so pošteni pri opravljanju & 2,69 \\
svojega dela. & $(2,66)$ \\
\hline Postopki davčne uprave so dovolj hitri. & 2,17 \\
\hline Davčna uprava ima dobro zabeležene vse potrebne & $(1,96)$ \\
podatke o davčnih zavezancih. & 2,86 \\
\hline Davčna uprava skrbi za obveščanje davko- & $(2,63)$ \\
plačevalcev o njihovih davčnih obveznostih. & 2,64 \\
\hline Davčna uprava sproti in dovolj obvešča o spremem- & $(2,43)$ \\
bah, ki so povezane z obdavčenjem. & 2,34 \\
\hline Davčna uprava je učinkovita pri odkrivanju davčnih & $(2,11)$ \\
\hline utaj. & 2,21 \\
\hline skupaj & $(1,79)$ \\
\hline
\end{tabular}

Iz tabele je razvidno, da se je mnenje zavezancev po dveh letih izboljšalo pri vseh trditvah. Najslabše je bila tokrat ocenjena trditev o hitrosti postopkov, šele nato pa sledi učinkovitost pri odkrivanju davčnih utaj. Najbolje je bila ocenjena trditev, da ima davčna uprava dobro zabeležene podatke o davčnih zavezancih. 
Visoko sta ocenjeni tudi trditvi o tem, da so zaposleni pošteni in so vedno pripravljeni pomagati.

Kakovost dela smo preverjali tudi z vprašanji, kako zavezanci ocenjujejo pomoč davčne uprave glede na druge oblike pomoči, ki jih uporabljajo. Kot najuporabnejšo obliko pomoči ocenjujejo delo računovodskih servisov in davčnih svetovalcev, saj je to pomoč kot zelo uporabno ali uporabno navedlo kar 96,5 \% vprašanih. Sledijo strokovni seminarji, ki so dobili visoke ocene pri $81,5 \%$ vprašanih, in pisna navodila, ki jih je z visoko stopnjo uporabnosti ocenilo kar 76,3 \% zavezancev. Tudi $\vee$ tej raziskavi so kot neuporabno zavezanci največkrat ocenili pomoč davčnega urada ali izpostave, in sicer kar 43,3 \% zavezancev. Najslabše je bil ocenjen obisk davčnega urada ali izpostave, in sicer je kar 51,6 \% zavezancev to pomoč ocenilo kot manj uporabno ali celo neuporabno.

Negativne izkušnje z davčno upravo je imelo 19,8 \% poslovne javnosti in 13,5 \% fizičnih oseb. Delež vprašanih, ki so imeli negativne izkušnje, se ni bistveno spremenil glede na leto 2000. Tudi $\vee$ tem primeru je kot glavni vzrok za negativno izkušnjo navedena nestrokovnost zaposlenih in dajanje različnih informacij (tudi nasprotujočih si) ter nepravočasnost pri odločanju. Pri ocenjevanju dela davčne administracije so ti zavezanci tudi kritičnejši, saj v povprečju delo davčne uprave vrednotijo slabše. Leta 2000 je bila povprečna ocena teh zavezancev za vse trditve le 1,85 , medtem ko je $v$ drugi raziskavi znašala 2,3. To pomeni, da tudi tisti, ki imajo negativne izkušnje $z$ davčno upravo, to $v$ povprečju bolje ocenjujejo.

Zavezanci so imeli na koncu vprašalnika možnost komentirati delo davčne uprave ali svoj odnos do davčnih obveznosti. Zavezanci so najbolj nezadovoljni z visokimi obrestmi in nepravočasnim obveščanjem o potencialnem dolgu. Posebej pa so nezadovoljni z nejasnostjo zakonodaje, ki jih sili k iskanju razlag iz različnih virov. Velikokrat se zgodi, da je razlaga na seminarjih v nasprotju z razlago DURS, srečujejo pa se celo z nasprotujočimi si navodili znotraj same DURS. Glede na povedano si želijo, da bi DURS sproti in čim natančneje obveščala zavezance o posameznih vprašanjih, povezanih z davki.

Zanimivo je, da se ugotovitve vseh omenjenih raziskav lahko primerjajo tudi z ugotovitvami raziskave $\vee 11$ državah članicah OECD. Rezultati raziskave, ki jo je OECD (2001b) izvedla med 11 članicami pri malih in srednje velikih podjetjih, kažejo, da zavezanci od vseh regulatornih organov najslabše ocenjujejo delo davčnih uprav. Raziskava je pokazala, da v povprečju polovica anketiranih podjetij ne dobi zadostnih informacij, povezanih z davki, na davčnih upravah. $\vee$ povprečju več kot 60 \% anketiranih meni, da se informacije o davkih med različnimi viri razlikujejo (torej je pomembno, kdo da informacijo). Anketirani so bili nezadovoljni tudi s hitrostjo posredovanja informacij. 


\section{Maja Klun \\ Merjenje kakovosti, usmerjenost $k$ uporabniku in davčna administracija}

\section{Zaključek}

Ugotovimo lahko, da imajo zavezanci v Sloveniji relativno pozitiven odnos do davkov in se trudijo pravilno izpolnjevati svoje davčne obveznosti. Odnos do dela DURS se izboljšuje in zavezanci imajo vse bolj pozitiven odnos do njenega dela. Zanimivo je, da pri vseh raziskavah izstopa nestrokovnost zaposlenih. Deloma je gotovo problem $v$ tem, da zaposleni na DURS, ki so največkrat $v$ stiku z zavezanci, resnično nimajo dovolj znanja za svetovanje $v$ konkretnih primerih, saj to ni njihova osnovna obveznost. Za navedeni problem je možnih več rešitev; ena je gotovo ta, da se zaposleni na teh delovnih mestih dodatno izobražujejo, predvsem $\vee$ poznavanju zakonodaje in pravil izpolnjevanja davčnih obveznosti zavezancev. Večinoma je znanje teh zaposlenih precej parcialno, dodatne informacije pa pridobijo predvsem z okrožnicami. Smiselno bi bilo razmisliti tudi o uvedbi informatorja na davčnih uradih, ki bi znal odgovoriti na najpogostejša in osnovna vprašanja zavezancev oz. napotiti zavezanca do prave osebe.

Če bo DURS tudi v prihodnosti izvajala ukrepe za izboljšanje kakovosti storitev, namenjenih zavezancem, predvsem pa si pridobila ugled $v$ javnosti, lahko $v$ prihodnosti pričakujemo višje ocene zavezancev za njeno delo.

\section{Literatura in viri}

- Baker, W. V. (1997): The Taxpayers' trust in the Tax Administration. Necessary Attributes for a Sound and Effective Tax Administration, CIAT, str. 183-199.

- Derganc, F. (2000): Prostovoljna davčna privolitev - cilj sodobne države? Davčni bilten, 1, št. 10, str. 23-25.

- DURS (2000): Napotki za učinkovito in prijazno komuniciranje s strankami. Priročnik za interno uporabo.

- $\quad$ DURS (1997): Strateški načrt DURS za obdobje 1998-2000.

- Hasseldine, J. (1998): Using Persuasive Communications to Increase Tax Compliance: What Experimental Research has (and has not) Told Us. (neobjavljeno delo)

- Kien, S., Siong, N. B. (1998): Transforming the Tax Collector: Reengineering the Inland Revenue Authority of Singapore. Journal of Organizational Change Management, 11, št. 6 , str. 496-514.

- Klun, M. (2002): Spodbujanje prostovoljnega izpolnjevanja davčnih obveznosti in učinkovitost davčne uprave, IX. Dnevi slovenske uprave, Zbornik referatov, Visoka upravna šola, str. 169-184.

- Konič, M., Arh, T. (2003): Podoba Davčne uprave RS v poslovni in široki javnosti. Davčni bilten, 3, št. 6, str. 29-30.

- Lebaube, R. A., Vehorn, C. L. (1992): Assisting Taxpayers in Meeting Obligations. V: Bird, Richard M., in Casanegra de Jantscher, Milka (ur.): Improving Tax Administration in Developing Countries. Washington, International Monetary Fund, str. 310-335.

- OECD - Centre for Tax Policy and Administration (2001a): Performance Measurement in Tax Administrations - Practicle Note. 


\section{Merjenje kakovosti, usmerjenost $k$ uporabniku in davčna administracija}

- $\quad$ OECD (2001b): Business' Views on Red Tape, Administrative and Regulatory Burdens on Small and Medium Sized Enterprises.

- OECD (1988): Administrative Responsiveness and the Taxpayer.

- Rains, L. C., Febres, J., Bes, M. (1997): Actions of the Tax Administration to Inform Taxpayers and Promote the Acceptance of Taxes by Society. V: Necessary Attributes for a Sound and Effective Tax Administration, CIAT, str. 201-246.

Maja Klun je doktorica ekonomskih znanosti in je zaposlena na Fakulteti za upravo. V svojem raziskovalnem delu se največ ukvarja s področjem javnih financ, predvsem z delovanjem davčnega sistema. 
Maja Klun

Merjenje kakovosti, usmerjenost $k$ uporabniku in davčna administracija

\section{SUMMARY}

\section{Quality Assessment, User-oriented Services and Tax Administration}

Quality assessment and user-oriented or customer-friendly service form a vital part of public sector reform and hence a vital part in the functional changes that are taking place in tax administrations around the world. If consultation services are well developed and tax administration operations sufficiently transparent, effectiveness also increases, primarily due to the higher level of voluntary tax declarations. Advice and consultation do not only involve direct relations between taxpayers and the administration regarding problems and queries, but also the preparation of clear instructions on tax payment, informing the public of changes in the system and organising informative workshops for taxpayers. These kinds of tax administration service can be divided into three basic categories: consultation, information and education for taxpayers. The main purpose of consulting taxpayers is to explain the complex, sometimes even contradictory legislative provisions covering an individual's tax liabilities.

At the end of the 1980s an OECD technical committee on relations between countries' public administrations and populations started its work with a project studying relations between taxpayers and the tax administration. Tax administration responsiveness was defined as its capacity to meet its customers' requirements. This tax administration responsiveness is expressed by providing customers with a polite and prompt reply and by improved communications between the two. The first part of the paper presents several examples of good practice from foreign tax administrations in this area.

The second part of the paper presents quality assessment of tax administration operations around the world. Quality can be assessed by internal bodies or outside experts, and its role is of considerable importance in assessing areas such as the legality of taxation procedures, professionalism, and compliance with standards. An OECD report states that most OECD countries use questionnaires to survey taxpayers' opinion about the work of the tax administration. The Norwegian tax administration regularly surveys taxpayers to assess its own work, while the Dutch tax administration always carries out public opinion research when changes are made to tax legislation. Denmark and Germany also perform surveys, though not on a regular basis. In some countries a number of public and private institutions survey taxpayer opinion. This is common in Finland, France, New Zealand, Spain, Sweden and the United States. In Canada, Mexico and the United Kingdom tax administrations regularly organise meetings for specific taxpayer groups 
and use these meetings to obtain feedback about their work. Other countries organise occasional surveys. Regardless of how often surveys are carried out their results do affect the work of the tax administrations.

The third part of the paper presents the quality assessment of the operations of the Slovenian tax administration. In its 1998-2000 strategy document the Tax Administration of the Republic of Slovenia (TARS) stated that it must take more action to encourage voluntary payment of tax liabilities by taxpayers, which will aid customer orientation and service quality. Surveying taxpayers is not a fixed part of TARS' quality assessment procedures. TARS has, however, ordered two public surveys: the research from November 1996 (carried out by the company Varianta, d. o. o.) and June 2003 (GralIteo). The Faculty of Administration carried out research in 2000 and 2002. Direct comparisons are not possible due to the different methods used, involving different questions and samples. Nevertheless, the paper does offer a comparison of general findings and an assessment of whether taxpayer opinions have improved between the times when the surveys were carried out.

It is important that the findings of all these research projects are broadly comparable to research findings from 11 OECD member countries. The research results, which the OECD carried out in SMEs in the 11 countries, indicate that taxpayers assess the tax administration as the worst of all regulatory bodies. On average over 60 per cent of respondents stated that information on taxes differs according to source (i.e. it is significant who provides the information). Respondents were unsatisfied with the speed at which information is provided. TARS has been subject to similar criticism and all the different research has revealed similar criticisms. Nevertheless, from the findings one can conclude that taxpayer assessments are improving every year. 